INTERNATIONAL FOOD

POLICY RESEARCH INSTITUTE

sustainable solutions for ending hunger and poverty

IFPRJ ${ }^{\circ} \quad$ supported by the CGIAR

IFPRI Discussion Paper 00839

December 2008

\title{
The Impact of Ethiopia's Productive Safety Net Programme and its Linkages
}

\author{
Daniel O. Gilligan \\ John Hoddinott \\ Alemayehu Seyoum Taffesse \\ Food Consumption and Nutrition Division \\ and \\ Development Strategy and Governance Division
}




\title{
INTERNATIONAL FOOD POLICY RESEARCH INSTITUTE
}

The International Food Policy Research Institute (IFPRI) was established in 1975. IFPRI is one of 15 agricultural research centers that receive principal funding from governments, private foundations, and international and regional organizations, most of which are members of the Consultative Group on International Agricultural Research (CGIAR).

\section{FINANCIAL CONTRIBUTORS AND PARTNERS}

IFPRI's research, capacity strengthening, and communications work is made possible by its financial contributors and partners. IFPRI receives its principal funding from governments, private foundations, and international and regional organizations, most of which are members of the Consultative Group on International Agricultural Research (CGIAR). IFPRI gratefully acknowledges the generous unrestricted funding from Australia, Canada, China, Finland, France, Germany, India, Ireland, Italy, Japan, Netherlands, Norway, South Africa, Sweden, Switzerland, United Kingdom, United States, and World Bank.

\section{AUTHORS}

Daniel O. Gilligan, International Food Policy Research Institute

Research Fellow, Food Consumption and Nutrition Division

John Hoddinott, International Food Policy Research Institute

Senior Research Fellow and Deputy Director, Food Consumption and Nutrition Division

\author{
Alemayehu Seyoum Taffesse, International Food Policy Research Institute \\ Research Fellow, Development Strategy and Governance Division
}

\begin{abstract}
Notices
${ }^{1}$ Effective January 2007, the Discussion Paper series within each division and the Director General's Office of IFPRI were merged into one IFPRI-wide Discussion Paper series. The new series begins with number 00689, reflecting the prior publication of 688 discussion papers within the dispersed series. The earlier series are available on IFPRI's website at www.ifpri.org/pubs/otherpubs.htm\#dp.

${ }^{2}$ IFPRI Discussion Papers contain preliminary material and research results. They have not been subject to formal external reviews managed by IFPRI's Publications Review Committee but have been reviewed by at least one internal and/or external reviewer. They are circulated in order to stimulate discussion and critical comment.
\end{abstract}




\section{Contents}

Acknowledgments $\quad \mathrm{V}$

Abstract $\quad$ vi

1. Introduction 1

2. Sampling Methodology, Questionnaire, and Survey Implementation 3

3. Evaluation Methodology 4

4. The PSNP and OFSP in Practice $\quad 6$

5. The Impact of the PSNP and OFSP $\quad 8$

6. Conclusion 18

$\begin{array}{ll}\text { References } & 19\end{array}$ 


\section{List of Tables}

1. Summary of outcome indicators 9

2. Average impact of any receipt of public works transfers 12

3. Average impact of public works transfers of at least 90 birr per household member 13

4. Average joint impact of Public Works (PW) and OFSP transfers 15 


\section{ACKNOWLEDGMENTS}

We thank the World Bank and the Department for International Development (DfID) of the United Kingdom for funding the work undertaken to produce this report. We are grateful to the late Ato Birhane of the Food Security Coordination Bureau in the Ministry of Agriculture and Rural Development of Ethiopia for his helpful comments on the results presented here. We also thank the staff of Ethiopia's Central Statistical Agency (CSA) and its Director General, Weizro Samia Zekaria, for their excellent work in implementing the survey used in this research.

We have benefited from helpful discussions with Ato Berhanu, Harold Alderman, Catherine Dom, Tim Robertson, Judith Sanford, and William Wiseman. We also received helpful comments from seminar participants in Addis Ababa and at the 2008 Oxford University Center for the Study of African Economies Conference on Economic Development in Africa. We also gratefully acknowledge comments from two anonymous referees and the editor.

It is a pleasure to acknowledge the superb research assistance provided by Nigussie Tefera and Yisehac Yohannes. Most importantly, we thank the thousands of Ethiopians who took the time to answer literally hundreds of questions about themselves and their experiences with the Productive Safety Net Programme (PSNP).

We are solely responsible for the contents of this paper. 


\begin{abstract}
This paper assesses the impact of Ethiopia's Productive Safety Nets Programme (PSNP), the largest social protection program in Sub-Saharan Africa outside of South Africa. Using Propensity Score Matching techniques, we find that the program has little impact on participants on average, due in part to transfer levels that fell far below program targets. Beneficiary households that received at least half of the intended transfers experienced a significant improvement in food security by some measures. However, households with access to both the PSNP and packages of agricultural support were more likely to be food secure, to borrow for productive purposes, use improved agricultural technologies, and operate their own nonfarm business activities. For these households, there is no evidence of disincentive effects in terms of labor supply or private transfers. However, estimates show that beneficiaries did not experience faster asset growth as a result of the programs.
\end{abstract}

Keywords: Productive Safety Net Programme, impact evaluation, food security, public works, Ethiopia 


\section{INTRODUCTION}

Chronic food insecurity has been a defining feature of the poverty that has affected millions of Ethiopians for decades. The vast majority of these extraordinarily poor households live in rural areas that are heavily reliant on rainfed agriculture; thus, in years of poor rainfall, the threat of widespread starvation is high. Since the 1983-1984 famine, the policy response to this threat has been a series of ad hoc emergency appeals on a near annual basis for food aid and other forms of emergency assistance which are then delivered either as payment for public works or as a direct transfer. While these measures succeeded in averting mass starvation, especially among those with no assets, they did not banish the threat of further famine, nor did they prevent asset depletion by marginally poor households affected by adverse rainfall shocks. As a result, the number of individuals in need of emergency food assistance rose from approximately 2.1 million people in 1996 to 13.2 million in 2003 before falling back to 7.1 million in 2004 (World Bank, 2004). Further, the ad hoc nature of these responses meant that the provision of emergency assistance-often in the form of food-for-work programs-was not integrated into ongoing economic development activities (Subbarao and Smith, 2003).

Starting in 2005, the Government of Ethiopia and a consortium of donors implemented a new response to chronic food insecurity in rural Ethiopia. Rather than annual appeals for assistance and ad hoc distribution programs, a three-year intervention called the Productive Safety Nets Programme (PSNP) was put into place. The objective of the PSNP is “... to provide transfers to the food insecure population in chronically food insecure woredas (districts) in a way that prevents asset depletion at the household level and creates assets at the community level” as well as bridging the food gap that arises when, for these households, food production and other sources of income are insufficient given food needs (Government of Ethiopia, 2004). The program operates as a safety net, targeting transfers to poor households in two ways - through public works (PW) and direct support (DS). Public works, the larger of the two programs, pays selected beneficiaries 6 Ethiopian birr per day (equivalent to approximately US\$0.75) $)^{1}$ for their labor on labor-intensive projects designed to build community assets. These activities are intended to occur between the months of January and June so as not to interfere with farming activities that in most regions occur in the second half of the year. Direct support, in the form of cash or food transfers, is provided to labor-scarce households, including those whose primary income earners are elderly or disabled, in order to maintain the safety net for the poorest households that cannot participate in public works. Depending on where they live, beneficiaries either receive cash or an equivalent payment in food, primarily wheat, maize and cooking oil. Beneficiaries are expected to remain in the PSNP for three years.

The PSNP is complemented by a series of food security activities, collectively referred to as the Other Food Security Programme (OFSP). Beneficiaries of the OFSP receive at least one of several productivity-enhancing transfers or services, including access to credit, agricultural extension services, technology transfer (such as advice on food crop production, cash cropping, livestock production, and soil and water conservation), and irrigation and water harvesting schemes. While the PSNP is designed to protect existing assets and ensure a minimum level of food consumption, the OFSP is designed to encourage households to increase income generated from agricultural activities and to build up assets. The OFSP has more limited coverage. In the 2006 survey conducted for this study, 32.7 percent of households engaged in public works employment under the PSNP received OFSP transfers or services.

Nearly all evaluations of social protection programs have centered on those in Latin America

and, to a lesser extent, South Asia. Evidence from Sub-Saharan Africa is much more limited; thus, it is of interest to examine the impact of a large-scale social protection program in an African setting. The PSNP reaches more than 7 million people and operates with an annual budget of nearly 500 million U.S. dollars. Outside of South Africa, it is currently the largest social protection program operating in

\footnotetext{
${ }^{1}$ This was increased to 8 birr per day in 2008 .
} 
Sub-Saharan Africa. There are, however, additional features of the PSNP that make an assessment of this program especially interesting.

Recent work has speculated that social protection programs may, in fact, be integral to policy frameworks that attempt to stimulate economic growth. In rural areas of Africa, there are pervasive credit and insurance market failures. This has two adverse consequences for agriculture: farmers are liquidity constrained (and therefore, for example, find it difficult to purchase fertilizer) and farmers are reluctant to take risks (for example, to adopt new crops). By providing liquidity and a reliable source of income, social protection addresses both types of market failures. Devereux (2008), Devereux et al. (2008), Dercon (2005), and Hoddinott (2008) provide further examples and references on this subject. An assessment of the PSNP offers insight as to whether these hypothesized benefits are realized in a large-scale program implemented in Africa.

Using matching methods, this paper assesses the impact of PSNP. In particular, it looks at whether, after 18 months of operation, the PSNP — on its own or together with the OFSP-reduced household food insecurity; raised consumption levels; encouraged households to engage in production and investment through enhanced access to credit; increased use of modern farming techniques and entry into nonfarm own business activities; and contributed to sustained asset accumulation. It also investigates whether these programs have had disincentive effects, measured in terms of reduced participation in the wage labor market or in the crowding out of private transfers. As is explained below, because implementation of the PSNP deviated from what was originally planned, we used several definitions of program participation. Under one definition, a household is considered a treatment household if it received any payment for undertaking work on PSNP-supported public works. Under a second definition, a household is considered a treatment household if it received at least half of the amount of transfers it should have received according to the design of the program. Under the third definition, a household is considered a treatment household if it received any payment for undertaking work on PSNP-supported public works and received access to any component of the OFSP during this period.

Using the first definition, we find little evidence of program impact. Under the second definition, access to the PSNP improves two measures of household food security: it reduces the likelihood that a household has very low caloric intake and it increases mean calorie availability. The largest impacts are found when we use the third definition of participation. Relative to the comparison group, households with access to both the PSNP and OFSP are more likely to be food secure, and are more likely to borrow for productive purposes, use improved agricultural technologies, and operate nonfarm own business activities. There is no evidence of displacement or disincentive effects in terms of the reduced supply of labor to wage employment or private transfers. However, relative to the comparison group, these households did not experience faster asset growth.

This paper begins by describing the data available to us and the methods used to assess impact. We then briefly review several aspects of the implementation of the PSNP, as these are relevant to the implementation and interpretation of our impact assessment, before we turn to the results themselves. 


\section{SAMPLING METHODOLOGY, QUESTIONNAIRE, AND SURVEY IMPLEMENTATION}

We use a quantitative household and community survey fielded between late June and early August, 2006, in the four principal regions served by the PSNP: Tigray, Amhara, Oromiya, and Southern Nations, Nationalities and People's Region (SNNPR). ${ }^{2}$ Within these regions, a sample of food-insecure woredas was selected in proportion to the overall number of chronically food-insecure woredas within that region and relative to the number of chronically food-insecure woredas in all four regions. Within each region, woredas were selected with probability proportional to size (PPS) based on the estimated chronically food insecure population (that is, the beneficiaries). The woredas were ordered geographically, in order to ensure geographical dispersion of the sample and to cover the range of agroecological conditions in each region. In total, 68 out of 190 woredas were selected.

Within woredas, enumeration areas (EAs) where the PSNP was active were identified. ${ }^{3}$ Restricting the sample to EAs with active Productive Safety Net Programmes, two enumeration areas per woreda were chosen using PPS sampling for Amhara, Oromiya, and SNNPR. In Tigray, three EAs per woreda were selected using PPS sampling. Twenty-five households were interviewed within each EA. Using separate lists of PSNP beneficiary and nonbeneficiary households, 15 PSNP beneficiary households and 10 nonbeneficiary households were selected for the sample using simple random sampling. This yielded a sample of 900 households each in Amhara and Tigray, and 950 households each in Oromiya and SNNPR, giving a sample size of 3,700.

Three limitations of the survey should be noted. First, it would have been preferable to field a survey in 2005 prior to the implementation of the PSNP in addition to the one conducted in 2006, as this would have readily permitted a "before-after" and "with-without" evaluation design. In the absence of a pre-intervention survey, we included a wide range of retrospective questions about household size and composition, assets, prior experiences with emergency assistance, and selected food security outcomes such as the size of the food gap. These questions, phrased retrospectively about such characteristics two years prior to the survey (that is, six months before the PSNP began), make it possible to re-create pre-baseline conditions for beneficiary and nonbeneficiary households. While this approach partly resolves the absence of a pre-program survey, it represents a second best solution as it may be subject to recall biases. A second limitation was that survey timing within the calendar year was good, but not ideal. The main agricultural season in Ethiopia runs from July to December, although there are regional variations within this period; for example, the season starts somewhat later in Tigray and Amhara. Given our survey's timing, we have extensive information on participation in PSNP activities from January to May 2006 (as well as from June to December 2005), but we miss any activities that occur in June or July 2006. Finally, the public works component involved the construction of community assets, which may benefit both households employed in their construction and also those households not employed in public works. If those employed received greater (lesser) benefits from these community assets, measured differences in outcomes across these groups will be enhanced (attenuated). Unfortunately, our data do not permit a distinction between the income-transfer effects of the PSNP and the effects of the creation of these community assets. However, if households employed in public works and those not employed in public works obtain similar benefits from the community assets, then our estimates of the impact of participation in the program provide unbiased estimates of the income transfer effects.

\footnotetext{
${ }^{2}$ Gilligan et al. (2007) provide a more detailed description of the survey.

3 “Active" means that program administrative structures were in place, there existed a list of beneficiaries, and the PSNP had provided assistance for at least one month in the last 12 months.
} 


\section{EVALUATION METHODOLOGY}

Access to the PSNP was not randomized. Consequently, we use Propensity Score Matching (PSM) to assess impact. This involves estimating a probit model that predicts the probability of each household receiving the PSNP as a function of (mostly pre-program) observed household and community characteristics using a sample of PSNP beneficiaries and nonbeneficiaries. The model specification is checked to test (and confirm) equality of the means of these observed characteristics across the beneficiary or "treatment" sample and the nonbeneficiary comparison group sample. In the impact estimates, the estimated probability of being in the program, or the "propensity score", from this model is used to determine the closeness (the "match") of treatment observations to neighboring nonbeneficiary comparison observations with similar values of the propensity score. The impact estimate is constructed as the average difference in the outcome of each beneficiary and a weighted average of nonbeneficiary outcomes, using the difference in propensity scores to construct the weights. Nonbeneficiaries with propensity scores nearest to the treatment observation receive the highest weight. ${ }^{4,5,6}$

PSM provides reliable estimates of program impact provided that (1) a comparable group of non-beneficiary households is available, and (2) there is access to carefully collected household survey data with many variables that are correlated with program participation and the outcome variables (Heckman, Ichimura and Todd, 1997, 1998). The PSNP sample was designed to include an appropriate comparison group. The sample is drawn exclusively from woredas operating in the PSNP, and roughly one-third of the sample is made up of nonbeneficiary households living in the same communities as PSNP beneficiaries. Also, the PSNP survey includes a large set of variables affecting household welfare and program participation. These variables include measures of household head age, gender, and schooling; household size and other demographic characteristics; asset levels before the program, distance to markets, indicators of social networks, exposure to economic shocks in the two years before the PSNP, and controls for unobserved woreda-level effects. ${ }^{7}$

Our approach assumes that after controlling for all pre-program observable household and community characteristics that are correlated with program participation and the outcome variable, nonbeneficiaries have the same average outcome as beneficiaries would have had if they did not receive the program. PSM provides biased estimates of program impact if, for any chosen outcome, it is not feasible to control for enough observable characteristics so that this assumption holds. Having nonbeneficiary households from the same communities as PSNP beneficiaries helps to reduce the risks of such bias by providing a similar distribution of unobserved community characteristics, such as access to markets or local economic shocks. Also, where it was possible to gather information on outcome variables from before the start of the program, outcomes can be measured as average changes

\footnotetext{
${ }^{4}$ The matching specification used is local linear matching with a tricube kernel using Stata's psmatch2 command (Leuven and Sianesi, 2003). Standard errors of the impact estimates are estimated by bootstrap using 100 replications.

${ }^{5}$ To confirm that the impact estimates using PSM are robust to the estimation method, we also estimated impacts using nearest neighbor matching (NNM) following Abadie et al. (2004). Rather than relying on propensity scores, NNM is a form of covariate matching that uses a multidimensional metric of the distance between values of the observable characteristics to construct the weighted average difference in outcomes. Results based on NNM differed little from the PSM estimates and, in the interests of brevity, are not reported here.

${ }^{6}$ Note that if the program was perfectly targeted, and if resources were available to cover all eligible beneficiaries, this approach would not be feasible, as it would not be possible to construct a statistically robust comparison group. However, there is considerable evidence that suggests that because of resource constraints, program access was rationed with the result that not all eligible households participated (Sharp, Brown and Teshome, 2006). These poor nonbeneficiaries form the basis of our comparison group.

${ }^{7}$ A technical appendix, available from the authors upon request, provides a complete list of variables used in estimating the propensity score models. Controls for woreda-level fixed effects in the matching model have the effect of making nonbeneficiary households from the same woreda as a treatment household contribute more to the impact estimate. On average, nonbeneficiaries from the same woreda as a treatment household receive greater weight in the construction of the comparison group average outcomes as a result of the use of woreda-level dummy variables.
} 
in the welfare measure since the start of the program. When outcomes can be measured in changes, we estimate the impact as the "difference in differences" (DID) in the outcome between the treatment and comparison group, rather than the "single difference" in outcomes between these two groups after the start of the program. DID estimates are known to be less subject to selection bias because they remove the effect of any unobserved time-invariant differences between the treatment and comparison groups.

We also assume that for each beneficiary household and for all observable characteristics, a comparison group of nonbeneficiaries with similar propensity scores exists. Heckman, Ichimura, and Todd $(1997,1998)$ emphasize that the quality of the match can be improved by ensuring that matches are formed only where the distribution of the density of the propensity scores overlap between treatment and comparison observations, or where the propensity score densities have "common support.” Common support is improved by dropping treatment observations whose estimated propensity score is greater than the maximum or less than the minimum of the comparison group propensity scores. Similarly, comparison group observations with a propensity score below the minimum or above the maximum of the treatment observations are also dropped. ${ }^{8}$ We also tested the "balancing properties" of the data by testing that treatment and comparison observations had the same distribution (mean) of propensity scores and of control variables within intervals (roughly quantiles) of the propensity score. All results presented below are based on specifications that passed the balancing tests.

\footnotetext{
${ }^{8}$ A shortcoming of this approach is that treatment observations near these cut points face a potential comparison group with propensity scores that are either all lower or all higher than that of the treatment observation. To account for this, we modified this "min/max" approach to identifying a region of common support using the following procedure. We estimated the probit model for program participation and identified the lower and upper cut points in the comparison or treatment groups. Only comparison observations were dropped in the left of the distribution and treatment observations were dropped on the right. We then added back the 5 percent of comparison observations from each tail that had been dropped that was closest in terms of propensity score. This involved adding back comparison observations cut from the lower tail of the distribution. In addition, we trimmed the treatment observations from the interior of the propensity score distribution that had the lowest density of comparison observations. We dropped two percent of treatment observations with this trimming procedure. In this common support sample, the probit model was estimated again to obtain a new set of propensity scores to be used in creating the match.
} 


\section{THE PSNP AND OFSP IN PRACTICE ${ }^{9}$}

\subsection{Targeting}

Within food insecure woredas served by the PSNP, chronically food-insecure households were identified using a mix of administrative guidelines and community knowledge. Chronic food security was defined as existing when a household faced continuous food shortages (usually three months of an annual food gap ${ }^{10}$ or more) in the last three years and received food assistance. Households that had experienced shocks that had led to severe asset losses were also eligible. Beneficiaries reported, on average, larger food gaps in the period prior to the implementation of the PSNP and they were considerably more likely to report having food gaps that exceeded three months prior to the implementation of the PSNP. Beneficiaries were more likely to have reported experiencing drought shocks and had, on average, lower levels of nonland assets. Participants in the Public Works program were more likely to come from male-headed households with a married head. PSNP beneficiaries had larger households, on average, than nonbeneficiaries in Tigray, Amhara, and Oromiya, but not in SNNPR.

\subsection{Provision of Work and Timeliness of Payment}

Not all households received PSNP benefits in both years that the program functioned. From the detailed questions asked about participation in public works, we know which households received at least one day of employment in the previous 12 months (approximately June 2005-May 2006). The survey also asked households if they had received assistance (food or cash for work, or free food or cash) in the 12-24 month period prior to the survey (that is, June 2004 to May 2005). Just over 22 percent of households that did not receive work between June 2005 and May 2006 reported receiving some assistance between June 2004 and May 2005. Half the households participating in public works between June 2005 and May 2006 had not received any assistance in the 12 months prior to that period. This shifting in and out of assistance programs means that the expected positive impact for public works participants may be less than expected because many current beneficiaries received benefits for only one year or less. Second, some of the households in the comparison group were food aid beneficiaries prior to the start of the PSNP in 2005. We might expect their food security and other welfare outcomes to be better than would be the case if they were "pure" controls who had not received any prior benefits. However, many PSNP beneficiaries had also been food aid recipients before 2005. We undertook several robustness checks of our results to examine whether prior access to food aid affected estimated program impact. A third concern is that the anticipated benefits associated with predictable transfer payments were lost, and this might affect the likelihood of risk-taking behavior such as adoption of new seeds.

Not only are there variations in access across years, but there are considerable differences in the amount of days worked across regions as well. Households in Tigray worked more days than households elsewhere, although the differences in days worked between Tigray, Amhara, and SNNPR in the period January-June 2006, are relatively small. In the same period, households in Oromiya worked significantly fewer days than households in other regions. As a result, there are marked regional variations in the size of transfers made to public works households. Between January and June 2006, Tigray households with members employed in public works received approximately 50 birr per month. Comparable figures for the other regions are 30 birr per month in Amhara, 39 birr per month in Oromiya, and 56 birr per month in SNNPR. However, proportionately these are smaller than the variations in days employed, reflecting significant wage arrears in both Tigray and Amhara. A study examining the payment process (construction of attendance sheets, payroll preparation, and so on)

\footnotetext{
${ }^{9}$ Gilligan et al. (2007) provide a detailed discussion of the implementation of the PSNP and OFSP.

${ }^{10}$ The food gap is defined as the number of months in the last 12 months that a household reports it had difficulty satisfying its food needs.
} 
found that, on average, 39 days elapsed between the preparation of public works' attendance sheets and payment to beneficiaries. Shortages of cashiers and lack of transport were two factors that significantly contributed to these arrears. (Department for International Development, U.K., 2007).

There are also regional differences in the amount of employment received. Households targeted for public works employment were planned to receive up to five days work per month for six months (at a wage of 6 birr per day or its equivalent in food) for each household member. Using our survey data, we calculated the ratio of the number of days of actual employment to the number of days of planned employment. For the period January-May 2006, mean values of this ratio range from a low of 0.23 in Oromiya to a high of 0.48 in Tigray. Because of wage arrears, the ratio of actual payments to planned payments is lower, ranging from a low of 0.11 in Amhara to 0.40 in SNNPR. If we restrict attention to a shorter, more recent period (March-May 2006), these ratios improve. The ratio of actual to planned employment is only 0.38 in Oromiya; elsewhere it is 0.71 in SNNPR, 0.73 in Amhara, and 0.80 in Tigray. But even in this period, actual payments lag planned payments, ranging from 0.10 in Amhara to 0.38 in SNNPR.

The fact that actual employment is often considerably less than planned employment, and the fact that there are significant wage arrears carry a number of implications, none of them beneficial to our assessment of impact. First, a key outcome is the number of months that a household has a food gap. Because these poor households are liquidity-constrained (that is, they have limited ability to borrow or save), their current consumption is tied fairly tightly to current income. So, even if households received full payment—albeit delayed—for their work, the existence of wage arrears makes it difficult for beneficiary households to reduce their food gap. Second, because observed payments ${ }^{11}$ are much lower than were planned, the ability of the program to increase asset levels (via savings out of transfer income) is circumscribed.

\subsection{Links to the Other Food Security Programme}

Access to the OFSP varied significantly by region. In Tigray, 69 percent of households that had obtained public works employment under the PSNP also reported receiving support from at least one component of the OFSP, and 49 percent reported receiving access to multiple components. More than 15 percent of these Tigrayan households reported receiving support from programs that provided access to improved seeds, irrigation and water-harvesting schemes, soil and water conservation, credit, the provision of livestock or of chicks; 27 percent received crop production extension services in the previous production year; and 56 percent had contact with a Development Agent (DA). Access to the OFSP was lower in Amhara, where 29 percent of households that had obtained public works employment under the PSNP also reported receiving support from at least one component of the OFSP, and 14 percent reported receiving access to multiple components. Only six percent received crop production extension services, and 29 percent had contact with a Development Agent. Access to the OFSP was even lower in Oromiya and SNNPR with 12 and 20 percent of households receiving services, respectively.

\footnotetext{
${ }^{11}$ A cautionary note to consider is that it is possible that households received payments for work undertaken in 2006 but received these after May 2006 (the last month for which our survey recorded payments).
} 


\section{THE IMPACT OF THE PSNP AND OFSP}

\subsection{Defining Program Participation}

These features of program implementation create challenges in terms of defining treatment and comparison group households. We used three definitions which, broadly speaking, correspond to increasing levels of program exposure.

\section{Definition 1}

A household is considered a treatment household if, in the period June 2005-May 2006, it received any payment for undertaking work on PSNP-supported public works. ${ }^{12}$ We refer to these households as PW-PSNP beneficiaries. A household is considered a comparison group household if, in the same period, it was either a non-PSNP participant or, while listed as a PSNP participant, did not receive any payments for public works activities. Households that received Direct Support are excluded from both treatment and comparison groups. ${ }^{13}$

Definition 2

A household is considered a treatment household if, in the period June 2005-May 2006, it received at least 90 birr per person, or food equivalent in value to 90 birr, for undertaking work on PSNP-supported public works. This treatment group represents those households that received at least half of the amount of transfers it should have received according to the design of the program. ${ }^{14} \mathrm{~A}$ household is considered a comparison group household if, in the same period, it was not a PSNP participant; that is, it did not supply any work or receive any payments for public works activities. Households that received Direct Support are excluded from both treatment and comparison groups. Definition 3

A household is considered a treatment household if, in the period June 2005-May 2006, it received any payment for undertaking work on PSNP-supported public works and, during this period, it received access to any component of the OFSP (such as access to improved seeds, irrigation and water-harvesting schemes, soil and water conservation, credit, the provision of livestock or of chicks, crop production extension services, or had contact with a Development Agent). We refer to these households as PW-PSNP-OFSP beneficiaries. A household is considered a comparison group household if, in the same period, it was either a non-PSNP participant or, while listed as a PSNP participant, did not receive any payments for public works activities and did not have access to any component of the OFSP. Households that received Direct Support are again excluded from both treatment and comparison groups.

Households that had been previous PSNP beneficiaries or past beneficiaries of emergency food assistance but are not current beneficiaries are included in the comparison group. Other things equal, this will tend to bias downward estimates of impact. To understand why, consider two households. One receives 100 birr from the PSNP in 2004-2005; the second receives an identical amount in 2005-2006. Under both definitions, the first household is part of the comparison group while the second is included

\footnotetext{
${ }^{12}$ A limitation of our study is that we cannot assess whether there were differential effects based on the form of payment, food or cash. The fundamental problem we face is that the distribution of recipients by form of payment is strongly affected by residence. For example, nearly all households in SNNPR received cash, whereas 70 per cent of Tigrayan beneficiaries received food. Wage arrears were much higher in Tigray than they were in SNNPR. Consequently, a "food-cash" comparison conflates comparisons by form of payment with other factors, making it difficult to assess the differential impact of food or cash. This is an unfortunate limitation given the considerable policy interest in this topic.

${ }^{13}$ We exclude participants receiving Direct Support for two reasons. First, because they are considerably poorer than nonbeneficiaries (see Gilligan et al. 2007), it is challenging to match them to nonbeneficiary households. Second, levels of transfers received by these households receiving Direct Support are very low. In Amhara, for example, between June and December 2005, monthly household transfers were 9 birr per Direct Support beneficiary household or, in dollar terms, just over US\$1 per household per month. Such low levels of transfers are unlikely to produce measurable impact.

${ }^{14}$ We considered a definition under which a treatment household was one that had received all benefits it was intended to receive. However, there were not enough beneficiaries to estimate impact under this definition.
} 
in the treatment group. Given that they received the same level of transfers, albeit in different years, it is not clear why the treatment group defined here will have higher levels of assets than the comparison group. ${ }^{15}$ Also, it would be helpful to understand which components of the OFSP had the greatest impact on outcomes of interest. Unfortunately, because coverage of the OFSP was so sparse, we did not have a sufficiently large sample to investigate this.

\subsection{Defining Outcomes}

We considered two sets of outcomes. The first is one that the PSNP and OFSP use as indicators that objectives are being met. For the PSNP, one critical indicator is the "food gap" (that is; the number of months in the last 12 months that a household reports that it had problems satisfying its food needs), a measure of household food security. A second indicator concerns asset holdings, as a goal of the PSNP is to prevent households from reducing their already low asset base. The OFSP has the objective of increasing income and asset levels, asset holdings, use of credit, and use of improved agricultural practices such as fertilizer and improved seeds (Government of Ethiopia, 2007). ${ }^{16}$

The second set of outcomes provides alternative measures of the program's outcome indicators. These include alternative measures of food security, such as caloric acquisition in the previous seven days; the magnitude of the food gap, and the number of meals children consume daily during the hungry season; per capita consumption, which can be thought of as a measure of the permanent income that flows from the household's stock of assets; and those that reflect common concerns that transfer programs have displacement or disincentive effects on labor supply and on private transfers.

Table 1 provides a brief summary of how these indicators were constructed. Mean values by treatment status are given in Tables 2, 3 and 4.

Table 1. Summary of outcome indicators

\begin{tabular}{|c|c|c|c|}
\hline Type of outcome & Outcome & How measured & Interpretation of sign \\
\hline \multirow[t]{3}{*}{$\begin{array}{l}\text { Household food } \\
\text { security }\end{array}$} & $\begin{array}{l}\text { Shortfall in caloric } \\
\text { availability }\end{array}$ & $\begin{array}{l}\text { Dummy variable equalling one if daily per } \\
\text { capita caloric acquisition in previous } 7 \text { days } \\
\text { (see below) is less than } 1,800 \text { kcal per person } \\
\text { per day. }\end{array}$ & $\begin{array}{l}\text { A negative value indicates that households } \\
\text { receiving program benefits were less likely } \\
\text { to be food secure. }\end{array}$ \\
\hline & $\begin{array}{l}\text { Daily per capita } \\
\text { caloric acquisition }\end{array}$ & $\begin{array}{l}\text { Respondents reported the consumption of } 33 \\
\text { different foods in the } 7 \text { days prior to the } \\
\text { interview from purchases, stocks and amounts } \\
\text { received as gifts, barter or in-kind payments. } \\
\text { Quantities were converted into calories } \\
\text { available for consumption and divided by } 7 \\
\text { (to get a daily figure) and by household size. }\end{array}$ & $\begin{array}{l}\text { A positive value indicates that households } \\
\text { receiving program benefits } \\
\text { acquired/consumed more calories. }\end{array}$ \\
\hline & $\begin{array}{l}\text { Change in months of } \\
\text { food security, 2004- } \\
2006\end{array}$ & $\begin{array}{l}\text { Difference between number of months } \\
\text { households report having no problems } \\
\text { satisfying the food needs of the household in } \\
\text { the last } 12 \text { months (approximately July 2005- } \\
\text { June 2006) and the } 12 \text { month period two years } \\
\text { prior (approximately July 2003-June 2004). }\end{array}$ & $\begin{array}{l}\text { A positive value indicates that households } \\
\text { receiving program benefits were more food } \\
\text { secure. }\end{array}$ \\
\hline
\end{tabular}

\footnotetext{
${ }^{15}$ We experimented with the definition of treatment to account for this. For example, we amended Definition 1 so that a treatment household is one that received PSNP benefits in both years preceding the survey, and a control household is one that received PSNP benefits in neither year. While this sharpened the difference between treatment and comparison households, it reduces sample size and therefore less statistical power. It did not produce additional results that inform our overall assessment of impact. We also modified the matching specification to include indicators for prior access to food aid. This change in specification did not meaningfully alter the results.

${ }^{16}$ The OFSP also aims to increase agricultural productivity. Preliminary investigations explored outcomes in this area too, but because the program yielded few significant impacts in this area, we have not reported on it here.
} 
Table 1. Continued

\begin{tabular}{|c|c|c|c|}
\hline Type of outcome & Outcome & How measured & Interpretation of sign \\
\hline \multicolumn{4}{|l|}{$\begin{array}{l}\text { Household food } \\
\text { security } \\
\text { (continued) }\end{array}$} \\
\hline & $\begin{array}{l}\text { Change in the square } \\
\text { of the food gap, } \\
2004-2006\end{array}$ & $\begin{array}{l}\text { Difference in the squared change in food gap } \\
\text { (defined as the number of months that } \\
\text { households had difficulty satisfying their food } \\
\text { needs) between 2005-2006 and 2003-2004. }\end{array}$ & $\begin{array}{l}\text { A negative value indicates that households } \\
\text { receiving program benefits were more food } \\
\text { secure. A negative value indicates a } \\
\text { reduction in the food gap and an } \\
\text { improvement in household food security. }\end{array}$ \\
\hline & $\begin{array}{l}\text { Number of } \\
\text { children's } \\
\text { meals/day, hungry } \\
\text { season }\end{array}$ & $\begin{array}{l}\text { The number of meals per day that children eat } \\
\text { during the month when food shortages are most } \\
\text { acute. }\end{array}$ & $\begin{array}{l}\text { A positive value indicates that children in } \\
\text { households receiving program benefits ate } \\
\text { more meals per day at the height of the hungry } \\
\text { season. }\end{array}$ \\
\hline Consumption & $\begin{array}{l}\text { Per capita } \\
\text { consumption }\end{array}$ & $\begin{array}{l}\text { Sum of per capita value of food and nonfood } \\
\text { expenditures. Food expenditures are based on } \\
\text { reports of he consumption of } 33 \text { different foods } \\
\text { in the } 7 \text { days prior to the interview from } \\
\text { purchases, stocks and amounts received as gifts, } \\
\text { barter or in-kind payments. These quantities } \\
\text { were converted to values (Ethiopian birr) using } \\
\text { household self-reports of purchases as well as } \\
\text { food prices reported in the community } \\
\text { questionnaire. Nonfood expenditures include } \\
\text { purchases of } 30 \text { nonfood items, including } \\
\text { clothing, kitchen equipment, furniture, } \\
\text { transport, ceremonies, contributions and } \\
\text { donations, fuel, lighting, soap, and tobacco. }\end{array}$ & $\begin{array}{l}\text { A positive value indicates that households } \\
\text { receiving program benefits had higher levels } \\
\text { of consumption of all goods (food and } \\
\text { nonfood). }\end{array}$ \\
\hline \multirow[t]{2}{*}{ Credit use } & Any credit use & $\begin{array}{l}\text { Dummy variable equalling one if household } \\
\text { reported taking out a loan of at least } 20 \text { birr in } \\
\text { the } 12 \text { months prior to the survey. }\end{array}$ & $\begin{array}{l}\text { A positive value indicates that households } \\
\text { receiving program benefits were more likely } \\
\text { to take out a loan in the last } 12 \text { months. }\end{array}$ \\
\hline & $\begin{array}{l}\text { Problems repaying } \\
\text { any loan }\end{array}$ & $\begin{array}{l}\text { Dummy variable equalling one if household } \\
\text { reported it had difficulty, is currently having } \\
\text { difficulty, or expects to have difficulty repaying } \\
\text { a loan taken out of } 20 \text { birr or more in the } 12 \\
\text { months prior to the survey. }\end{array}$ & $\begin{array}{l}\text { A negative value indicates that households } \\
\text { receiving program benefits were less likely to } \\
\text { have difficulties repaying loans. }\end{array}$ \\
\hline \multirow[t]{2}{*}{$\begin{array}{l}\text { Use of improved } \\
\text { agricultural } \\
\text { technologies }\end{array}$} & Use of fertilizer & $\begin{array}{l}\text { Dummy variable equalling one if the household } \\
\text { reported using any fertilizer between June } 2005 \\
\text { and the date of interview. }\end{array}$ & $\begin{array}{l}\text { A positive value indicates that households } \\
\text { receiving program benefits were more likely } \\
\text { to use fertilizer. }\end{array}$ \\
\hline & $\begin{array}{l}\text { Use of improved } \\
\text { seed }\end{array}$ & $\begin{array}{l}\text { Dummy variable equalling one if the household } \\
\text { reported using improved seed between June } \\
2005 \text { and the date of interview. }\end{array}$ & $\begin{array}{l}\text { A positive value indicates that households } \\
\text { receiving program benefits were more likely } \\
\text { to use improved seeds. }\end{array}$ \\
\hline \multirow[t]{2}{*}{$\begin{array}{l}\text { Own business } \\
\text { activity }\end{array}$} & $\begin{array}{l}\text { Any nonfarm own } \\
\text { business activity in } \\
\text { past } 12 \text { months }\end{array}$ & $\begin{array}{l}\text { Dummy variable equalling one if at least one } \\
\text { household member had undertaken an off-farm } \\
\text { business activity such as weaving, other } \\
\text { handicrafts, trade, the collection and sale of } \\
\text { firewood or dung cakes, or the manufacture and } \\
\text { sale of processed foods in the } 12 \text { months prior } \\
\text { to the survey. }\end{array}$ & $\begin{array}{l}\text { A positive value indicates that households } \\
\text { receiving program benefits were more likely } \\
\text { to participate in an off-farm business activity. }\end{array}$ \\
\hline & $\begin{array}{l}\text { Entry into nonfarm } \\
\text { own business in } \\
\text { past } 2 \text { years }\end{array}$ & $\begin{array}{l}\text { Dummy variable equalling one if a household } \\
\text { member started a nonfarm own business } \\
\text { activity in the last two years. }\end{array}$ & $\begin{array}{l}\text { A positive value indicates that households } \\
\text { receiving program benefits were more likely } \\
\text { to start an off-farm business at some point in } \\
\text { the last } 2 \text { years. }\end{array}$ \\
\hline Assets & $\begin{array}{l}\text { Change in log } \\
\text { value of livestock } \\
\text { and tools, } \\
\text { 2004-2006 }\end{array}$ & $\begin{array}{l}\text { Difference in the log values of livestock and } \\
\text { agricultural tools owned by the household in } \\
2004 \text { and } 2006 \text {. }\end{array}$ & $\begin{array}{l}\text { A positive value indicates that households } \\
\text { receiving program benefits increased their } \\
\text { holdings of these assets between } 2004 \text { and } \\
2006 \text {. }\end{array}$ \\
\hline $\begin{array}{c}\text { Labor market } \\
\text { participation }\end{array}$ & $\begin{array}{l}\text { Any wage } \\
\text { employment by } \\
\text { males in past } 12 \\
\text { months }\end{array}$ & $\begin{array}{l}\text { Dummy variable equalling one if at least one } \\
\text { male household member undertook wage } \\
\text { employment in the } 12 \text { months prior to the } \\
\text { survey. }\end{array}$ & $\begin{array}{l}\text { A positive value indicates that in households } \\
\text { receiving program benefits, men were more } \\
\text { likely to undertake wage work. }\end{array}$ \\
\hline
\end{tabular}


Table 1. Continued

\begin{tabular}{|c|c|c|c|}
\hline \multirow[t]{4}{*}{$\begin{array}{l}\text { Labor market } \\
\text { participation } \\
\text { (continued) }\end{array}$} & $\begin{array}{l}\text { Any wage } \\
\text { employment by } \\
\text { females in past } 12 \\
\text { months }\end{array}$ & $\begin{array}{l}\text { Dummy variable equalling one if at least one } \\
\text { female household member undertook wage } \\
\text { employment in the } 12 \text { months prior to the } \\
\text { survey. }\end{array}$ & $\begin{array}{l}\text { A positive value indicates that in households } \\
\text { receiving program benefits, women were } \\
\text { more likely to undertake wage work. }\end{array}$ \\
\hline & $\begin{array}{l}\text { Entry by males into } \\
\text { wage employment } \\
\text { in past } 2 \text { years }\end{array}$ & $\begin{array}{l}\text { Dummy variable equalling one if a male } \\
\text { household member entered wage employment } \\
\text { in the last two years. }\end{array}$ & $\begin{array}{l}\text { A positive value indicates that males in } \\
\text { households receiving program benefits were } \\
\text { more likely to enter the wage labor market at } \\
\text { some point in the last } 2 \text { years. }\end{array}$ \\
\hline & $\begin{array}{l}\text { Entry by females } \\
\text { into wage } \\
\text { employment in past } \\
2 \text { years }\end{array}$ & $\begin{array}{l}\text { Dummy variable equalling one if a female } \\
\text { household member entered wage employment } \\
\text { in the last two years. }\end{array}$ & $\begin{array}{l}\text { A positive value indicates that females in } \\
\text { households receiving program benefits were } \\
\text { more likely to enter the wage labor market in } \\
\text { the last } 2 \text { years. }\end{array}$ \\
\hline & $\begin{array}{l}\text { Any positive net } \\
\text { transfers received } \\
\text { from others }\end{array}$ & $\begin{array}{l}\text { Dummy variable equalling one if net transfers } \\
\text { to the household in the last } 12 \text { months (transfers } \\
\text { received minus transfers made) were greater } \\
\text { than zero. }\end{array}$ & $\begin{array}{l}\text { A negative value indicates that households } \\
\text { receiving program benefits were less likely to } \\
\text { be net beneficiaries of private transfers. }\end{array}$ \\
\hline $\begin{array}{c}\text { Transfers and } \\
\text { remittances }\end{array}$ & $\begin{array}{l}\text { Value of net } \\
\text { transfers received } \\
\text { from others }\end{array}$ & $\begin{array}{l}\text { Value of net transfers received from other } \\
\text { households (transfers in cash and in- kind } \\
\text { received minus transfers in cash and in-kind } \\
\text { made). }\end{array}$ & $\begin{array}{l}\text { A negative value indicates that households } \\
\text { receiving program benefits received lower ne } \\
\text { private transfers. }\end{array}$ \\
\hline
\end{tabular}

\subsection{Assessment of Impact Using Access to the PSNP as Treatment}

Following the discussion of Definition 1, treatment households are those that received any payment for undertaking work on PSNP-supported public works. We estimate impact by region and for all observations aggregated. Because we consider 19 different outcomes, we have nearly 100 impact estimates. Given this number, rather than comment on each impact in each region, we focus on the full sample results found in Table 2. An appendix to this paper (available from the authors on request) provides results separately by region.

Given the objectives of the PSNP, we are particularly interested in the outcome indicators for household food security. Strikingly, under this definition of treatment, there is no evidence that the PSNP improves food security for beneficiaries relative to the comparison group. Table 2 also shows that asset levels of these beneficiaries did not fall, which was a major objective of the program. Between 2004 and 2006, the nominal value of beneficiaries' assets, livestock and tools increased by just under 45 per cent. Nevertheless, while treatment households experienced positive growth in their asset holdings (and this was true in all four regions), comparison group households experienced even faster asset growth, thus resulting in a negative program impact. Credit use by PSNP beneficiaries increased, a result driven largely by increased demand for consumption credit. When the results were disaggregated by region, we see that this finding is driven largely by results from Amhara. This is an unwelcome development. Given the delays in payments for public works in Amhara, this result is consistent with PW-PSNP beneficiary households taking out loans (possibly backed by future payments from public works employment) to finance current consumption. Access to the public works component of the PSNP increased the likelihood that households undertook their own business activities, but slightly reduced the likelihood that males entered the wage labor market. 
Table 2. Average impact of any receipt of public works transfers

\begin{tabular}{|c|c|c|c|}
\hline & \multicolumn{2}{|c|}{ Mean } & \multirow[b]{2}{*}{ Impact } \\
\hline & Public works & Non-public works & \\
\hline \multicolumn{4}{|l|}{ Household food security } \\
\hline & 0.294 & 0.311 & -0.017 \\
\hline Caloric acquisition is less than $1,800 \mathrm{kcal} /$ day/capita in last 7 days & & & $(0.448)$ \\
\hline & 2,485 & 2,431 & 54.24 \\
\hline Daily per capita caloric acquisition in last 7 days & & & $(0.669)$ \\
\hline & 0.228 & 0.063 & 0.164 \\
\hline Change in months of food security, 2004-2006 & & & $(1.414)$ \\
\hline Change in the square of the food gap, 2004-2006 & -1.378 & 0.025 & $\begin{array}{l}-1.403 \\
(1.118)\end{array}$ \\
\hline Number of children’s meals/day, hungry season & 2.667 & 2.698 & $\begin{array}{l}-0.031 \\
(0.718)\end{array}$ \\
\hline \multicolumn{4}{|l|}{ Consumption } \\
\hline Per capita total expenditure & 79.76 & 83.02 & $\begin{array}{c}-3.264 \\
(1.558)\end{array}$ \\
\hline \multicolumn{4}{|l|}{ Credit use } \\
\hline Any credit use & 0.367 & 0.296 & $\begin{array}{c}\mathbf{0 . 0 7 1} * * * \\
(2.872)\end{array}$ \\
\hline Problem repaying any loan & 0.113 & 0.098 & $\begin{array}{c}0.015 \\
(0.843)\end{array}$ \\
\hline \multicolumn{4}{|l|}{ Use of improved agricultural technologies } \\
\hline Use of fertilizer & 0.186 & 0.187 & $\begin{array}{c}-0.001 \\
(0.066)\end{array}$ \\
\hline Use of improved seeds & 0.048 & 0.037 & $\begin{array}{c}0.011 \\
(1.117)\end{array}$ \\
\hline \multicolumn{4}{|l|}{ Own business activity } \\
\hline Any nonfarm own business activity in past 12 months & 0.241 & 0.189 & $\begin{array}{c}\mathbf{0 . 0 5 2} * * * \\
(2.872)\end{array}$ \\
\hline Entry into nonfarm own business in past 2 years & 0.075 & 0.060 & $\begin{array}{c}0.015 \\
(1.191)\end{array}$ \\
\hline \multicolumn{4}{|l|}{ Assets } \\
\hline Change in log value of livestock and tools, 2004-06 & 0.448 & 0.673 & $\begin{array}{c}\mathbf{- 0 . 2 2 5} * * * \\
(2.776)\end{array}$ \\
\hline \multicolumn{4}{|l|}{ Labor market participation } \\
\hline Any wage employment by males in past 12 months & 0.249 & 0.251 & $\begin{array}{c}-0.003 \\
(0.124)\end{array}$ \\
\hline Any wage employment by females in past 12 months & 0.079 & 0.079 & $\begin{array}{c}-0.001 \\
(0.042)\end{array}$ \\
\hline Entry by males into wage employment in past 2 years & 0.058 & 0.088 & $\begin{array}{c}-\mathbf{0 . 0 3 0} * * \\
(2.106)\end{array}$ \\
\hline Entry by females into wage employment in past 2 years & 0.019 & 0.024 & $\begin{array}{l}-0.006 \\
(0.913)\end{array}$ \\
\hline \multicolumn{4}{|l|}{ Transfers and remittances } \\
\hline Any positive net transfers received from others & 0.107 & 0.097 & $\begin{array}{c}0.009 \\
(0.724)\end{array}$ \\
\hline Value of net transfers received from others & 5.139 & -5.194 & $\begin{array}{c}10.33 \\
(0.766)\end{array}$ \\
\hline
\end{tabular}

Note: Estimates for daily caloric acquisition per capita and caloric acquisition of at least 1,800 kcal/day/capita are based on a trimmed sample of households with daily caloric acquisition per capita of at least 1,200 kcal and not more than 4,800 kcal. Estimates for per capita food expenditure and per capita total expenditure are based on samples in which the top 5 percent and bottom 5 percent of the expenditure distribution were removed for each variable in order to reduce the effect of severe outliers. Absolute value of t-statistics in parentheses is based on bootstrapped standard errors. * significant at the 10 percent level; ${ }^{* *}$ significant at the 5 percent level; $* * *$ significant at the 1 percent level. Sample sizes: $\mathrm{n}_{\mathrm{B}}=1,234, \mathrm{n}_{\mathrm{NB}}=524$. 


\subsection{Assessment of Impact Using the 90 Birr per Household Member Definition of Household Participation in the PSNP}

Under Definition 2, treatment households are those that received payments of at least 90 birr per person for work on PSNP-supported public works in the period June 2005-May 2006. Results are reported in Table 3. Using this definition, we find that one measure of household food security-the likelihood that a household has very low caloric intake-improves (in the full sample). There was also an increase in per capita caloric acquisition. This increase is not statistically significant for the full sample, but is significant in Tigray, the area for which the region-specific sample was largest. As with Definition 1, there is increased likelihood of nonfarm business activities and reduced entry into the wage labor market. The increase in nonfarm activities may reflect increased household liquidity, and payments under the PSNP may be financing start-up costs associated with these enterprises. This increased liquidity may also explain why problems with loan repayment have been reduced. While there is a significant reduction in the likelihood of entry into wage employment, the interpretation of this result should be done cautiously. This result may reflect a disincentive effect; that is, PSNP beneficiaries were less likely to enter wage employment because they were receiving transfers. Alternatively, access to the PSNP may have been displacing entry into wage employment, with beneficiaries opting to work for the PSNP instead. Regional disaggregations show that males in Tigrayan households were particularly less likely to enter the wage labor market, and Tigray is the region where males worked the most number of days. This observation is consistent with the displacement argument. It raises the concern that Public Works activities are crowding out labor supply to private labor markets, which could produce upward pressure on wages. In order to have a clear assessment of whether the PSNP is having a disincentive effect on labor supply, we would need to know the total number of hours worked by households in our sample. Unfortunately, such data are not available.

\section{Table 3. Average impact of public works transfers of at least 90 birr per household member}

\begin{tabular}{|c|c|c|c|}
\hline & \multicolumn{3}{|c|}{ Full sample } \\
\hline & \multicolumn{2}{|c|}{ Mean } & \multirow[b]{2}{*}{ Impact } \\
\hline & Public works & Non-public works & \\
\hline \multicolumn{4}{|l|}{ Household food security } \\
\hline Caloric acquisition is less than $1,800 \mathrm{kcal} /$ day/capita in last 7 days & 0.277 & 0.381 & $\begin{array}{l}-\mathbf{0 . 1 1 2} * * \\
(2.036)\end{array}$ \\
\hline Daily per capita caloric acquisition in last 7 days & 2551 & 2368 & $\begin{array}{l}183.4 \\
(1.568)\end{array}$ \\
\hline Change in months of food security, 2004-06 & 0.410 & 0.252 & $\begin{array}{l}0.158 \\
(0.833)\end{array}$ \\
\hline Change in the square of the food gap, 2004-06 & 5.697 & 3.629 & $\begin{array}{l}2.067 \\
(0.647)\end{array}$ \\
\hline Number of children's meals/day in hungry season & 2.739 & 2.785 & $\begin{array}{l}-0.046 \\
(0.609)\end{array}$ \\
\hline \multicolumn{4}{|l|}{ Consumption } \\
\hline Per capita total expenditure & 89.55 & 94.49 & $\begin{array}{l}-4.94 \\
(1.182)\end{array}$ \\
\hline \multicolumn{4}{|l|}{ Credit use } \\
\hline Any credit use & 0.351 & 0.363 & $\begin{array}{l}-0.012 \\
(0.290)\end{array}$ \\
\hline Problem repaying any loan & 0.093 & 0.161 & $\begin{array}{l}-\mathbf{0 . 0 6 8} * * \\
(2.005)\end{array}$ \\
\hline \multicolumn{4}{|l|}{ Use of improved agricultural technologies } \\
\hline Use of fertilizer & 0.188 & 0.201 & $\begin{array}{l}-0.014 \\
(0.437)\end{array}$ \\
\hline Use of improved seeds & 0.039 & 0.078 & $\begin{array}{l}-0.039 \\
(1.490)\end{array}$ \\
\hline
\end{tabular}




\begin{tabular}{|c|c|c|c|}
\hline & \multicolumn{3}{|c|}{ Full sample } \\
\hline & \multicolumn{2}{|c|}{ Mean } & \multirow[b]{2}{*}{ Impact } \\
\hline & Public works & Non-public works & \\
\hline \multicolumn{4}{|l|}{ Own business activity } \\
\hline Any nonfarm own business activity in past 12 months & 0.241 & 0.171 & $\begin{array}{l}\text { 0.065** } \\
(2.122)\end{array}$ \\
\hline Entry into nonfarm own business in past 2 years & 0.070 & 0.884 & $\begin{array}{l}-0.018 \\
(0.628)\end{array}$ \\
\hline \multicolumn{4}{|l|}{ Assets } \\
\hline Change in log value of livestock and tools, 2004-06 & 0.478 & 0.662 & $\begin{array}{l}-0.185 \\
(1.570)\end{array}$ \\
\hline \multicolumn{4}{|l|}{ Labor market participation } \\
\hline Any wage employment by males in past 12 months & 0.228 & 0.257 & $\begin{array}{l}-0.029 \\
(0.770)\end{array}$ \\
\hline Any wage employment by females in past 12 months & 0.168 & 0.221 & $\begin{array}{l}-0.053 \\
(0.549)\end{array}$ \\
\hline Entry by males into wage employment in past 2 years & 0.035 & 0.145 & $\begin{array}{l}-\mathbf{0 . 1 1 0} * * * \\
(3.00)\end{array}$ \\
\hline Entry by females into wage employment in past 2 years & 0.020 & 0.018 & $\begin{array}{l}0.002 \\
(0.175)\end{array}$ \\
\hline \multicolumn{4}{|l|}{ Transfers and remittances } \\
\hline Any positive net transfers received from others & 0.087 & 0.090 & $\begin{array}{l}-0.003 \\
(0.120)\end{array}$ \\
\hline Value of net transfers received from others & -3.50 & -28.44 & $\begin{array}{l}24.93 \\
(0.975)\end{array}$ \\
\hline
\end{tabular}

Note: See Table 2. Sample sizes in matched samples for PW beneficiaries and PW nonbeneficiaries are 485 and 234 , respectively.

\subsection{Assessment of Impact Using Access to the PSNP and OFSP as Treatment}

Under Definition 3, households were considered beneficiaries if they received any payment for undertaking work on PSNP-supported public works and they received access to at least one intervention or service provided under the OFSP.

The striking feature of the results reported in Table 4 is the relatively large number 7 out of 19) of statistically significant impacts at the 5 percent level; with an eighth significant at the 10 percent level. Relative to the comparison group, PW-PSNP-OFSP beneficiaries are more likely to be food secure, to borrow for productive purposes, and to use improved agricultural technologies. There is no evidence that PW-PSNP-OFSP participation reduces labor supply to the wage labor market by either men or women, or crowds out private transfers.

Table 4 shows no difference between treatment and comparison group households in the prevalence of current household food security, as measured by whether the household had available for consumption 1,800 kilocalories per person per day. However, mean caloric availability is higher by nearly 10 percent in PW-PSNP-OFSP beneficiary households compared to the comparison group. ${ }^{17}$ When we disaggregate by region, we find that while this positive impact is most marked in Tigray, it is also observed in Amhara and SNNPR. In terms of the food gap, a key outcome measure for the FSP, the PW-PSNP-OFSP has a sizeable (1.6 months) positive impact on this measure of food security in Tigray. Across all sampled households, food security improved by 0.36 months among PW-PSNPOFSP beneficiary households when compared to the comparison group, and this impact is statistically significant at the 5 percent level. Further, the severity of the food gap is reduced as shown by the negative and statistically significant impact on the change in the square of the food gap. ${ }^{18}$

\footnotetext{
${ }^{17}$ As a specification check, we also estimated impact after transforming this variable to logs. Doing so did not qualitatively change these findings.

${ }^{18}$ We considered four other coping strategies. We found no impact on meal frequency by adults during the hungry
} 
Table 4. Average joint impact of Public Works (PW) and OFSP transfers

\begin{tabular}{|c|c|c|c|}
\hline & \multicolumn{3}{|c|}{ Full sample } \\
\hline & \multicolumn{2}{|c|}{ Mean } & \multirow[b]{2}{*}{ Impact } \\
\hline & Public works & Non-public works & \\
\hline \multicolumn{4}{|l|}{ Household food security } \\
\hline Caloric acquisition is less than $1,800 \mathrm{kcal} /$ day/capita in last 7 days & 0.271 & 0.321 & $\begin{array}{c}-0.050 \\
(1.023)\end{array}$ \\
\hline Daily per capita caloric acquisition in last 7 days & 2577 & 2347 & $\begin{array}{c}230.0 * * * \\
(2.608)\end{array}$ \\
\hline Change in months of food security, 2004-06 & 0.361 & -0.008 & $\begin{array}{c}\mathbf{0 . 3 6 9 * *} \\
(2.351)\end{array}$ \\
\hline Change in the square of the food gap, 2004-06 & -2.918 & 0.317 & $\begin{array}{c}-3.325^{* *} \\
(2.457)\end{array}$ \\
\hline Number of children's meals/day, hungry season & 2.738 & 2.695 & $\begin{array}{c}0.044 \\
(0.556)\end{array}$ \\
\hline \multicolumn{4}{|l|}{ Household consumption expenditure } \\
\hline Per capita total expenditure & 88.16 & 86.33 & $\begin{array}{c}1.826 \\
(0.619)\end{array}$ \\
\hline \multicolumn{4}{|l|}{ Credit use } \\
\hline Any credit use & 0.401 & 0.279 & $\begin{array}{c}\text { 0.123** } \\
(2.512)\end{array}$ \\
\hline Problem repaying any loan & 0.137 & 0.062 & $\begin{array}{c}\mathbf{0 . 0 7 5} * * * \\
(3.202)\end{array}$ \\
\hline \multicolumn{4}{|l|}{ Use of improved agricultural technologies } \\
\hline Use of fertilizer & 0.267 & 0.160 & $\begin{array}{c}\mathbf{0 . 1 0 7} * * * \\
(3.021)\end{array}$ \\
\hline Use of improved seeds & 0.082 & 0.033 & $\begin{array}{c}\text { 0.048** } \\
(2.298)\end{array}$ \\
\hline \multicolumn{4}{|l|}{ Own business activity } \\
\hline Any nonfarm own business activity in page 12 months & 0.252 & 0.186 & $\begin{array}{l}0.067^{*} \\
(1.754)\end{array}$ \\
\hline Entry into nonfarm own business in past 2 years & 0.070 & 0.052 & $\begin{array}{c}0.025 \\
(1.152)\end{array}$ \\
\hline \multicolumn{4}{|l|}{ Assets } \\
\hline Change in log value of livestock and tools, 2004-2006 & 0.466 & 0.523 & $\begin{array}{c}-0.057 \\
(0.427)\end{array}$ \\
\hline \multicolumn{4}{|l|}{ Labor market participation } \\
\hline Any wage employment by males in past 12 months & 0.296 & 0.252 & $\begin{array}{c}0.043 \\
(1.124)\end{array}$ \\
\hline Any wage employment by females in past 12 months & 0.089 & 0.076 & $\begin{array}{c}0.013 \\
(0.587)\end{array}$ \\
\hline Entry by males into wage employment in past 2 years & 0.082 & 0.076 & $\begin{array}{c}0.006 \\
(0.246)\end{array}$ \\
\hline Entry by females into wage employment in past 2 years & 0.024 & 0.015 & $\begin{array}{c}0.009 \\
(0.883)\end{array}$ \\
\hline \multicolumn{4}{|l|}{ Transfers and remittances } \\
\hline Any positive net transfers received from others & 0.099 & 0.108 & $\begin{array}{l}-0.009 \\
(0.352)\end{array}$ \\
\hline Value of net transfers received from others & 10.35 & -4.422 & $\begin{array}{c}14.77 \\
(0.888)\end{array}$ \\
\hline
\end{tabular}

Note: See Table 2. Sample sizes in matched samples for PW beneficiaries and PW nonbeneficiaries are 416 and 223 , respectively.

season nor on consumption of less preferred foods or consumption of wild foods. Puzzlingly, there was a slight increase in the consumption of saved seeds. We are unsure how to interpret this result, given the absence of impacts on other coping strategies. It is possible that PW-PSNP-OFSP beneficiaries are able to save more seeds relative to households in the comparison group, and thus they can consume more of these seeds during periods of stress. 
One of the objectives of the OFSP is to increase households' use of credit. Achieving this goal requires actions on both the demand and supply side of the credit market; that is, households must be willing to borrow and there must be availability of funds that can be borrowed. Table 4 shows that credit use by PW-PSNP-OFSP beneficiaries was 12 percentage points higher than the comparison group, an increase driven entirely by the increase in demand for credit for production purposes. ${ }^{19}$ Given that production credit was made available under the OFSP, this result is not entirely surprising. However, there was an increase in the likelihood that households borrowing for production purposes reported that they had, or anticipated having, difficulties in repaying these loans. Fear of difficulty in repaying loans was cited as the reason they did not borrow money during the previous 12 months by 36 percent and 44 percent of households in Tigray and Amhara, respectively. Particularly in Tigray and Amhara, many of the loans taken by households appear to have been relatively large (the median loan size for all surveyed households that borrowed money is 500 and 429 birr, respectively) and it may be that these relatively large loans were proving to be challenging to repay.

There was a strikingly large increase in the use of fertilizer, of nearly 10.7 percentage points, by PW-PSNP-OFSP beneficiaries. This represents a sharp increase relative to the comparison group, where only 16 percent of households used fertilizer. Moreover, there were broadly similar point estimates of impact found in all regions. There was an increase of 4.8 percentage points in the use of improved seeds, albeit from a very low base and this, too, was found across all regions. ${ }^{20}$

PW-PSNP-OFSP does not appear to crowd out nonfarm own business activities; in fact, relative to comparison group households, beneficiaries of these programs are 6.7 percentage points more likely to operate these enterprises. There is likewise no evidence to suggest that PW-PSNP-OFSP crowds out private transfers, or that it reduces participation in wage employment.

Finally, we considered whether PW-PSNP-OFSP beneficiaries experience more rapid asset growth than comparison group households. While participants in these programs do experience asset growth, they do so at a slower rate than comparable comparison group households, suggesting that by itself the PSNP and OFSP programs are not raising the rate of asset accumulation. As a check on the robustness of these findings, we examined other forms of asset accumulation-such as improvements in housing stock — but do not find any evidence of program impact.

An important question is whether the larger impacts for households that received PW and OFSP (as opposed to just PW) are due entirely to the incremental effect of OFSP or to greater involvement in PW as well. We examined whether PW beneficiaries that also received OFSP worked more days or received higher transfers than PW beneficiaries on average. In the full sample, PW beneficiaries who also received OFSP worked an average of 7 more days in PW per household member during the past 12 months. Also, PW beneficiary households that also received OFSP earned an average of 20 birr more per household member from PW in the past 12 months than the full sample of PW beneficiaries.

These results suggest that the greater impacts found for joint PW-OFSP participation were due in part to higher transfers from PW for households in this sample. ${ }^{21}$ However, given the relative difference in the size of impacts for PW-OFSP beneficiaries compared to PW beneficiaries, it is unlikely that most of this effect was due to a difference in PW receipts of only 20 birr (which amounts

\footnotetext{
${ }^{19}$ We also estimated the impact of access to PW-PSNP-OFSP on the size of these loans. Relative to comparison households, beneficiaries took out larger loans for production purposes; there was no difference in the size of consumption loans.

${ }^{20}$ We assessed impact of the programs on use of pesticides but found no evidence that access to the PW-PSNP-OFSP increased their usage.

${ }^{21}$ It could be argued that differences in the samples used to construct the impact estimates for PW-PSNP and those for joint receipt of PW-PSNP and OFSP may be contributing to the differences in observed impacts. However, in the matched samples that satisfied all requirements to be included in the impact estimates, there were 1,758 household observations for the PW-PSNP impact analysis, and 639 household observations for estimating the joint impact of PW-PSNP and OFSP. This difference in sample sizes would provide greater statistical power to the sample used for the PW-PSNP analysis; thus, it is unlikely that differences in sample size were responsible for the stronger impacts observed for joint PW-PSNP and OFSP participation.
} 
to a 21 percent increase in PW receipts). Also, these results reflect regional differences in both the coverage of OFSP and in the impact of PW and the OFSP. PW beneficiaries in Tigray were much more likely to receive the OFSP. Half of all joint beneficiaries-those receiving PW and the OFSP in the sample—came from Tigray.

We also considered what components of the OFSP may have been responsible for the positive impacts of this program when provided with PW transfers. Although the evaluation design and sample do not permit constructing separate impact estimates for each component of the OFSP, the prevalence of each component among OFSP benefits received is informative. More than half of the joint beneficiaries received soil and water conservation (SWC) services, ${ }^{22}$ and almost 40 percent received credit. Nearly one-third of the joint beneficiaries received irrigation services. Receiving improved seeds, and having access to pasture or livestock were also common, with 18 percent of joint beneficiaries claiming access in each of these categories.

\footnotetext{
${ }^{22}$ It is worth noting that 85 percent of OFSP beneficiaries received other services, so the SWC activities indicated by respondents are not entirely responsible for the observed joint PW-OFSP impacts. Also, 25 percent of households who received SWC support from the OFSP also received extension services.
} 


\section{CONCLUSION}

This paper has used Propensity Score Matching to assess the impact of Ethiopia's Productive Safety Nets Programme and Other Food Security Programme after their first 18 months of operation. As noted in the Introduction, the PSNP is the largest social protection program in Sub-Saharan Africa outside of South Africa. Our findings are subject to three caveats:

1. At the time of data collection, the program had only been operational for 18 months. For this reason, this should be considered as an interim assessment of program impact. A survey conducted in 2008 will give insights into longer-run effects of the program.

2. Despite the substantial strengths of this data set, one weakness is that the data were collected more than one year after the program began, so the set of pre-PSNP household and community characteristics used to match beneficiaries and nonbeneficiaries had to be collected through recall.

3. Deviations between planned and actual program implementation downwardly bias estimates of impact.

We note that an assessment of these programs depends critically on how participation is defined. Our matching estimates find little evidence of program impact when participation is defined in terms of receiving any payment for undertaking work on PSNP-supported public works. However, we found no evidence that asset levels shrank, which was a key objective of the PSNP program. Somewhat stronger evidence of impact emerges when we define participation in terms of households receiving at least half of their intended transfers; here, one measure of household food security (caloric acquisition above a minimum threshold) was improved. A more positive picture emerges when participation in both the PSNP and OFSP is considered. Relative to the comparison group, participants are more likely to be food secure, and are more likely to borrow for productive purposes, use improved agricultural technologies, and operate nonfarm own business activities. For these households, there was no evidence of disincentive effects in terms of the reduced supply of labor to wage employment or private transfers. Although asset levels grew, relative to the comparison group, beneficiaries did not experience faster asset growth. It remains to be seen whether continued participation in the PSNP and OFSP will result in future growth in assets. 


\section{REFERENCES}

Abadie, A., D. Drukker, J. L. Herr, and G. W. Imbens. 2004. Implementing matching estimators for average treatment effects in Stata. Stata Journal 4(3): 290-311.

Dercon , S., ed. 2005. Insurance against poverty. Oxford: Oxford University Press.

Department for International Development, United Kingdom. 2007. PSNP Fiduciary Risk Analysis. Mimeo, Addis Ababa.

Devereux, S. 2008. Targeting social safety nets to support agricultural growth in rural areas. Paper presented at the international conference: Convergence between Social Service Provision (SSP) and Productivity Enhancing Investments (PEI) in Development Strategies. Pietermaritzburg, South Africa: University of KwaZulu-Natal.

Devereux, S., Al-Hassan, R. Dorward, A., Guenther, B., Poulton, C., and R. Sabates-Wheeler. 2008. Linking social protection and support to small farmer development. Paper commissioned by the Food and Agriculture Organization of the United Nations (FAO). Rome: FAO.

Government of Ethiopia. 2007. Food security programme logical framework. Addis Ababa: Ministry of Agriculture and Rural Development.

2004. Productive Safety Net Programme: Programme Implementation Manual. Addis Ababa: Ministry of Agriculture and Rural Development.

Gilligan, D., J. Hoddinott, A. S. Taffesse, S. Dejene, N. Tefera, and Y. Yohannes. 2007. Ethiopia Food Security Programme: Report on 2006 baseline survey. Mimeo. Washington, D.C.: International Food Policy Research Institute.

Heckman, J. J., H. Ichimura, and P. E. Todd. 1997. Matching as an econometric evaluation estimator: Evidence from evaluating a job training programme. Review of Economic Studies 64 (4): 605-654.

. 1998. Matching as an econometric evaluation estimator. Review of Economic Studies 65 (2): 261-294.

Hoddinott, J. 2008. Social safety nets and productivity enhancing investments in agriculture. Paper presented at the international conference, Convergence between Social Service Provision (SSP) and Productivity Enhancing Investments (PEI) in Development Strategies. Pietermaritzburg, South Africa: University of KwaZulu-Natal.

Leuven, E., and B. Sianesi. 2003. PSMATCH2: Stata module to perform full Mahalanobis and propensity score matching, common support graphing, and covariate imbalance testing. http://ideas.repec.org/c/boc/bocode/s432001.html. Version 1.2.3

Sharp, K., Brown, T., and Teshome, A. 2006. Targeting Ethiopia’s Productive Safety Net Programme. London: Overseas Development Institute.

Subbarao, K., and J. Smith. 2003. Safety nets versus relief nets: Toward a medium term safety net strategy for Ethiopia. Mimeo. Washington, D.C.: World Bank.

World Bank. 2004. Project Appraisal Document for a Productive Safety Net Project. Report No. 29767-ET. Washington, D.C.: World Bank. 



\section{RECENT IFPRI DISCUSSION PAPERS}

\section{For earlier discussion papers, please go to www.ifpri.org/pubs/pubs.htm\#dp. All discussion papers can be downloaded free of charge.}

838. Aid effectiveness and capacity development: Implications for economic growth in developing countries. Prabuddha Sanyal and Suresh Babu, 2008.

837. A two-dimensional measure of polarization. Tewodaj Mogues, 2008.

836. Higher fuel and food prices: Economic impacts and responses for Mozambique. Channing Arndt, Rui Benfica, Nelson Maximiano, Antonio M.D. Nucifora, and James T. Thurlow, 2008

835. Accelerating innovation with prize rewards: History and typology of technology prizes and a new contest design for innovation in African agriculture. William A. Masters and Benoit Delbecq, 2008.

834. Local politics, political institutions, and public resource allocation. Nethra Palaniswamy and Nandini Krishnan, 2008.

833. Trade protection and tax evasion: Evidence from Kenya, Mauritius, and Nigeria. Antoine Bouet and Devesh Roy, 2008.

832. Global carbon markets: Are there opportunities for Sub-Saharan Africa? Elizabeth Bryan, Wisdom Akpalu, Mahmud Yesuf, and Claudia Ringler, 2008.

831. Anatomy of a crisis: The causes and consequences of surging food prices. Derek Heady and Shenggen Fan, 2008

830. Credit constraints, organizational choice, and returns to capital: Evidence from a rural industrial cluster in China. Jianqing Ruan and Xiaobo Zhang, 2008.

829. The future of global sugar markets: Policies, reforms, and impact. Proceedings of a public conference. Jean-Christophe Bureau, Alexandre Gohin, Loïc Guindé, Guy Millet, Antônio Salazar P. Brandão, Stephen Haley, Owen Wagner, David Orden, Ron Sandrey and Nick Vink, 2008.

828. The impact of climate change and adaptation on food production in low-income countries: Evidence from the Nile Basin, Ethiopia. Mahmud Yesuf, Salvatore Di Falco, Claudia Ringler, and Gunnar Kohlin, 2008.

827. The Philippines: Shadow WTO agricultural domestic support notifications. Caesar Cororaton, 2008.

826. What determines adult cognitive skills?: Impacts of preschooling, schooling, and post-schooling experiences in Guatemala. Jere R. Behrman, John Hoddinott, John A. Maluccio, Erica Soler-Hampejsek, Emily L. Behrman, Reynaldo Martorell, Manuel Ramírez-Zea, andAryeh D. Stein, 2008.

825. Accelerating Africa's food production in response to rising food prices: Impacts and requisite actions. Xinshen Diao, Shenggen Fan, Derek Headey, Michael Johnson, Alejandro Nin Pratt, Bingxin Yu, 2008.

824. The effects of alternative free trade agreements on Peru: Evidence from a global computable general equilibrium model. Antoine Bouët, Simon Mevel, and Marcelle Thomas, 2008.

823. It's a small world after all. Defining smallholder agriculture in Ghana. Jordan Chamberlin, 2008

822. Japan: Shadow WTO agricultural domestic support notifications. Yoshihisa Godo and Daisuke Takahashi, 2008.

821. United States: Shadow WTO agricultural domestic support notifications. David Blandford and David Orden, 2008.

820. Information flow and acquisition of knowledge in water governance in the Upper East Region of Ghana. Eva Schiffer, Nancy McCarthy, Regina Birner, Douglas Waale, and Felix Asante, 2008.

819. Supply of pigeonpea genetic resources in local markets of Eastern Kenya. , Patrick Audi, and Richard Jones, 2008.

818. Persistent poverty and welfare programs in the United States. John M. Ulimwengu, 2008.

817. Social learning, selection, and HIV infection: Evidence from Malawi. Futoshi Yamauchi and Mika Ueyama, 2008.

816. Evaluating the impact of social networks in rural innovation systems: An overview. Ira Matuschke, 2008.

815. Migration and technical efficiency in cereal production: Evidence from Burkina Faso. Fleur S. Wouterse, 2008.

814. Improving farm-to-market linkages through contract farming: A case study of smallholder dairying in India. Pratap S. Birthal, Awadhesh K. Jha, Marites M. Tiongco, and Clare Narrod, 2008. 


\section{INTERNATIONAL FOOD POLICY RESEARCH INSTITUTE}

www.ifpri.org

IFPRI HEADQUARTERS

2033 K Street, NW

Washington, DC 20006-1002 USA

Tel.: +1-202-862-5600

Fax: +1-202-467-4439

Email: ifpri@cgiar.org

IFPRI ADDIS ABABA

P. O. Box 5689

Addis Ababa, Ethiopia

Tel.: +251 116463215

Fax: +251 116462927

Email: ifpri-addisababa@cgiar.org

IFPRI NEW DELHI

CG Block, NASC Complex, PUSA

New Delhi 110-012 India

Tel.: 9111 2584-6565

Fax: 9111 2584-8008 / 2584-6572

Email: ifpri-newdelhi@cgiar.org 